\title{
AdVANCES IN (UN)CONVENTIONAL ENGINEERING OF BIOMATERIALS AND NuRSING CARE
}

\author{
HLOCH, S.; FOLDYNA, J.; MONKA, P.; \\ KOZAK, D. \& MAGUROVA, D.
}

Abstract: The paper defines the current state of the art in the sphere of utilization of conventional and unconventional techniques of cutting and machining of the bone tissue in orthopaedic surgery and related issues. Paper refers to the possibilities of the water jet technology utilization during (re)implantations of total endoprostheses of large joints aimed at minimizing the bone losses and thermo-mechanical damage to the bone tissue. Outlined are main problems and potential improvement by application of progressive water jet technique. Paper summarizes up-to-date research of the team. Reason of the research is to develop the surgical technique, without heat and mechanical damage of large joints, with minimal traumatizing effects on the patient and a maximum yield for the society.

Key words: biomaterial, cutting, orthopaedy, femoral channel, bone, bone cement
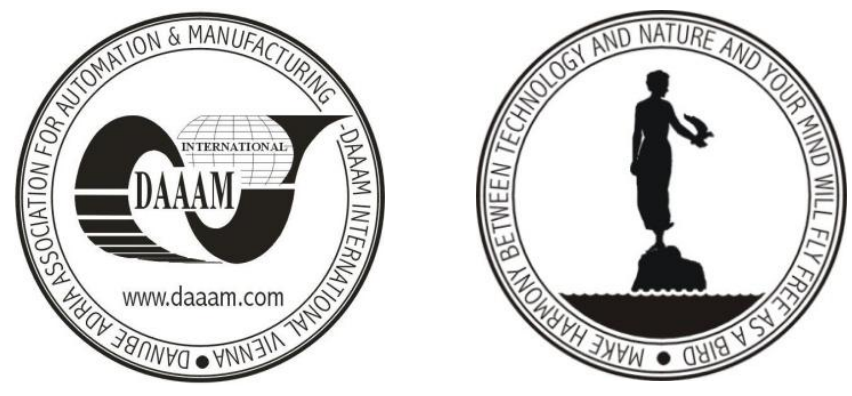

Authors' data: Hloch, S[ergej]*; Foldyna, J[osef]*; Monka, P[eter]**; Kozak, $\mathrm{D}$ [razan]***; Magurova, D[agmar]****; * Institute of Geonics Academy of Science of Czech Republic, v.v.i., Ostrava Poruba, Czech Republic; ** Faculty of Manufacturing Technologies, Technical University of Košice with a seat in Prešov, Prešov, Slovakia; *** Josip Juraj Strossmayer University of Osijek, Mechanical Engineering Faculty in Slavonski Brod, Croatia; **** Faculty of Health Care, University of Prešov, Slovakia; sergej.hloch@tuke.sk, peter.monka@tuke.sk

This Publication has to be referred as: Hloch, S[ergej]; Foldyna, J[osef]; Monka, $\mathrm{P}$ [eter]; Kozak, D[razan] \& Magurova, D[agmar] (2013) Advances in (Un)Conventional Engineering of Biomaterials and Nursing Care, Chapter 13 in DAAAM International Scientific Book 2013, pp. 297-316, B. Katalinic \& Z. Tekic (Eds.), Published by DAAAM International, ISBN 978-3-901509-94-0, ISSN 17269687, Vienna, Austria

DOI: $10.2507 /$ daaam.scibook.2013.13 


\section{Introduction}

In the course of the last decades orthopaedic surgery has been developing rapidly. A significant qualitative change is being noted at present when the development of technical and biological sciences is moving the field of orthopaedic surgery forward (Ritter \& Campbell, 1989), (Salgado et al., 2004). New knowledge in the sphere of basic research and in the modern field in question have formed preconditions and substantial possibilities of technique in case of conventional orthopaedic surgical operations such as correction of uneven length and deformations of limbs, osteosynthesis, but particularly in possibilities of replacements of worn-out degenerative joints either on the developing, inflammatory, traumatogenic, metabolic grounds or in the postoperative states (Kloc, 2009). Number of patients suffering from degenerative joint diseases (osteoarthritis) has been continually increasing and due to its seriousness, therapeutic complications and frequent patient/client $(\mathrm{p} / \mathrm{c})$ individualization the disease represents inherent and significant medical, economic and social issue. The successful replacement of the destroyed joint means improvement of mobility, pain relief and returning back to accomplishing every day activities for a $\mathrm{p} / \mathrm{c}$.

Many patients at working age re-enter into an employment relationship after successful surgery related to the total endoprosthesis. Achievement of implantation and reimplantation of the total hip joint replacement and long-term longevity of endoprosthesis depend on number of factors involving, for instance, correct surgery indication, patient preparation, properly performed surgical operation. A surgical operation rests chiefly in selection and effective technique of the bone cutting which influence both quality and biological potential of the generated surface. Utilization of up-to-date techniques may cause frequent revision surgical operations. An aseptic loosening of endoprosthesis represents the most common reason of subsequent implantation failure. A long-term success of the implanted endoprosthesis does not lie only in the used surgical techniques but also in the method of cutting and machining of the bones, their properties and technological procedures (Hreha et al., 2010). Measuring micro and macro characteristics of the bone is insufficient for the assessment of cutting conditions in terms of inhomogenity of the bone for the cortical and spongy bone parts (Kato et al., 1998), (Jackson et al., 2005).

\section{State of The Art Analysis in Biomaterials (Un)Conventional Cutting}

The design of osteotomes as we know them today dates back to the 17th or 18th century. These tools, chisels, toothed saws and knives, were copied from those used in the wood industry (Giraud et al., 1991). Surgeons' tools only included a few technical improvements compared with those commonly used for cutting other materials. The bone cutting (Hreha et al., 2010), (Giraud et al., 1991), (Sugita et al., 2009), (Haider et al., 2007) issue is currently an existing problem of more surgeons even in regard to the fact that the bone tissue is compact and living material (Kato et al., 1998), (Giraud et al., 1991). 


\begin{tabular}{|c|c|c|}
\hline $\begin{array}{l}\text { Osteotomy } \\
\text { techniques }\end{array}$ & Purpose description & Reference \\
\hline Drilling & \multirow{2}{*}{$\begin{array}{l}\text { Biocompatibility, perforation } \\
\text { Thermal bone necrosis research, } \\
\text { decreasing axial force, drill geometry }\end{array}$} & \multirow{2}{*}{$\begin{array}{l}\text { (Giraud et al., 1991) } \\
\text { (Udiljak et al., 2007) } \\
\text { (Lee et al., 2011) }\end{array}$} \\
\hline High speed drilling & & \\
\hline Milling & \multirow{2}{*}{$\begin{array}{l}\text { Minimally invasive orthopaedic surgery, } \\
\text { cortical bone reconstruction, surface } \\
\text { preparation }\end{array}$} & \multirow{2}{*}{$\begin{array}{l}\text { (Haider et al., 2007) } \\
\text { (Sugita et al., 2009) }\end{array}$} \\
\hline High speed milling & & \\
\hline Sawing & Thermal effects, study & $\begin{array}{c}\text { (Ark et al., 1998), } \\
\text { (Toksvig-Larsen et al., } \\
\text { 1992) }\end{array}$ \\
\hline $\begin{array}{l}\text { Coated cutting } \\
\text { tools }\end{array}$ & Diamond-coated cutting tool & (Jackson et al., 2005) \\
\hline Microcutting & Bone precision cutting & (Mitsuishi et al., 2002) \\
\hline Laser beam & $\begin{array}{l}\text { Rotational Acetabular Osteotomy (RAO), } \\
\text { to understand changes } \\
\text { induced in bone in terms of temperature } \\
\text { rise and thermal damage, } \\
\text { feasibility of performing complete } \\
\text { oesteotomy, examine bone healing } \\
\text { under functional loading, vertical ramus } \\
\text { osteotomy }\end{array}$ & $\begin{array}{c}\text { Lustman et al., 1991), } \\
\text { (Nelson et al., 1988), } \\
\text { (Biyikli \& Modest, } \\
\text { 1987), (Siebert, 1993), } \\
\text { (Jahn et al., 1992), } \\
\text { (Wallace et al., 2004), } \\
\text { (Armengol et al., } \\
\text { 1999), (Yoshikazu, } \\
\text { 2011), } \\
\text { (Papadaki et al., 2007) }\end{array}$ \\
\hline $\begin{array}{l}\text { Ultrasonic } \\
\text { machining }\end{array}$ & $\begin{array}{l}\text { To correct conditions of the jaw and face, } \\
\text { to achieve a correct bite, } \\
\text { an aesthetic face and an enlarged airway, } \\
\text { sinus lift, alveolar ridge expansion, } \\
\text { exposure of impacted canines, } \\
\text { lateralization of the } \\
\text { inferior alveolar nerve removal of osseous } \\
\text { tissue close to the IAN, } \\
\text { orthognathic surgery, autologous bone } \\
\text { graft, harvesting, periodontal } \\
\text { surgery, IAN transposition, alveolar } \\
\text { distraction osteogenesis, and the } \\
\text { removal of osseointegrated implants }\end{array}$ & $\begin{array}{c}\text { (Giraud et al., 1991), } \\
\text { (Steiger et al., 1996), } \\
\text { (Caillouette et al., } \\
\text { 1991), } \\
\text { (Klapper et al., 1992), } \\
\text { (O'Daly et al., 2008) }\end{array}$ \\
\hline Water jet & $\begin{array}{l}\text { Selection, cold cutting of soft tissues, } \\
\text { destruction of bone cement, small forces }\end{array}$ & $\begin{array}{l}\text { (Richter et al., 2009) } \\
\text { (Oertel et al., 2003) }\end{array}$ \\
\hline Abrasive water jet & $\begin{array}{l}\text { Endoprothesis revision surgery, bone } \\
\text { cutting, femoral component cutting }\end{array}$ & $\begin{array}{l}\text { (Honl et al., 2000) } \\
\text { (Honl et al., 2001) } \\
\text { (Honl et al., 2003) }\end{array}$ \\
\hline Pulsating water jet & Bone cement removal & (Hloch et al., 2013) \\
\hline
\end{tabular}

Tab.1. Bone cutting techniques 
Hloch, S.; Foldyna, J.; Monka, P.; Kozak, D. \& Magurova, D.: Advances in (Un)Co...

A significant part of the clinical and non-clinical studies has been conducted to assess performance of machining techniques with utilization of diverse technological conditions. The following table 1 presents conventional (Udiljak et al., 2007), (Lee et al., 2011), (Sugita et al., 2009), (Nelson \& Weber, 1981), (Ark et al., 1998), (Toksvig-Larsen et al., 1992) and non-conventional methods (Lustman et al., 1991), (Nelson et al., 1988), (Biyikli \& Modest, 1987), (Siebert, 1993), (Jahn et al., 1992), (Wallace et al., 2004), (Armengol et al., 1999), (Yoshikazu, 2011), (Papadaki et al., 2007), of the bone tissue cutting or (Dunnen et al., 2013) drilling with water jet.

Typical measuring of the cutting and machining performance relates to the surface texture, surface integrity, cutting force, temperature, and bone healing after cutting, efficiency, mechanical tension, and cutting accuracy (Giraud et al., 1991), (Udiljak et al., 2007). To select a correct procedure of the bone machining, it is important to be aware of the fact that the bone is a complex biomaterial and in terms of mechanical properties it shows certain particularities in dependence on the structure, location, stress direction, stress history (Kl'oc, 2009), (Jackson et al., 2005). It is typical due to structural inhomogeneity and anisomery. The bone consists of a thick and compact external tissue, i.e. cortical bone. The bone core is composed of porous and spongy tissue referred to as the spongy bone. The cortical bone is anisotropic and characterized by three different Young's modules (Kato et al., 1998).

Mechanical properties of the bone vary in dependence on sex, age, anatomy, nutrition. Nowadays in the field of the bone tissue cutting there are mechanical tools being used which frequently represent invasive intervention into the organism of the individual. While in the first part of the last century chisels (Nelson \& Weber, 1981) and manual saws (Giraud et al., 1991) were preferred, at present an air-powered saw with special indications and high-speed milling (Sugita et al., 2009) cutters and drills (Udiljak et al., 2007), (Lee et al., 2011) are used. Utilization of the aforementioned conventional instruments in (re)implantation of total endoprostheses brings along several drawbacks, e.g. increase of risk of disintegration, cracking and various other complications (Ritter \& Campbell, 1989), (Eriksson \& Albrektsson, 1994), (Krause et al., 1982), (Toksvig-Larsen, et al., 1991), (Biyikli, et al., 1986), (Wächte \& Stoll, 1991), (Johansson et al.1, 1981). The existing technological advances referred to decrease of the required effort of a surgeon in cutting and to increase osteotomy speed in time with respect to operating parameters. In many publications particular attention is continually devoted to the issue of enhancement of the bone tissue cutting by conventional method (Johansson et al.l, 1981), (Canestri, 1992), (Sugita et al., 2005), (Mitsuishi et al., 2003), (Taylor \& Stoianovici, 2003), (Kwon et al., 2002), (Mitsuishi et al., 2002). Professor Udiljak (Udiljak et al., 2007) and Tomislav Staroveski (Goran et al., 2012) studied the problem of avoiding the occurrence of irreversible death of bone cells exposed to high temperature during drilling. Jackson et al (Jackson et al., 2005) in their investigation used diamond-coated cutting tool to prepare bone for biomedical implants. He found that bending of the cutting tool contributes significantly to the primary chip prior to significant frictional interactions on the rake face of the cutting tool. 
Haider et al. (Haider et al., 2007) reported a concept to eliminate alignment jigs and facilitate smaller arthroplasty incisions. His paper (Haider et al., 2007) has been awarded by HAP Paul Award. A new cutting method for bone on its crack propagation characteristics has been introduced by Sugita et al (2009). This method realizes high efficiency, low mechanical stress and high precision in the bone machining. In study of (Sugita \& Mitsuishi, 2009) micro cutting of the bovine cortical bone was performed and structure observed under a microscope. Two research trends have referred to improvements focused primarily on motorization of the cutting movements and tools (Canestri, 1992), (Sugita et al., 2005), (Mitsuishi et al., 2003), (Taylor \& Stoianovici, 2003), (Kwon et al., 2002), (Mitsuishi et al., 2002). Implementation of the automatized cutting represents the most significant technical upgrade for a surgeon. Several diverse types of mechanical drives for cutting are used with each drive connected to various tools and control of their action of force. The concept of the dynamically controlled milling was designed by a research team headed by Sugita (Sugita et al., 2009). In the regime of force control the software monitors cutting forces through which temperature reduction is allowed. The authors assessed the influence of cutting time shortening, overload of a tool, protection against temperature increase, and safety check enhancement of action of force of a tool on the basis of real-time monitoring. The use of a coolant as a prevention of the tissue necrosis and utilization of tools sharpened in advance have been described by the same characteristics in the so far published theses (Toksvig-Larsen, et al., 1991).

Yet the question whether the given recommendations are accepted by surgeons arises. In the course of the bone cutting a blade of a saw is being cooled as the heat generated in contact between a tool and the bone tissue has a negative influence upon biological potential of the bone. The drilling equipment is effective, especially in combination with robotic systems (Udiljak et al., 2007), (Lee et al., 2011), (Kwon et al., 2002). Their accuracy is better in comparison with oscillating saws (Giraud et al., 1991), (Ark et al., 1998), (Toksvig-Larsen et al., 1992) yet alike in the aforementioned instance the heat generated as a result of friction during drilling represents a drawback for the bone quality. A substantial positive feature of chisels (Nelson \& Weber, 1981) contrary to sawing and drilling stems in the unchanged bone tissue vitality. Using a chisel frequently causes damaging of the soft tissue by a sharp blade. The method is utilized in osteotomy techniques to prolong the bone since not a maximal accuracy is required but a biological potential of the purposefully destroyed bone surface. Oscillating saws may represent a necrosis source in the moment of a slip occurrence causing penetration into other living tissues. Efficiency of a surgery is decreased because oscillating instruments reach a zero speed even in two positions. Problematic is also a cutting width which is relatively wide in dependence on spacing of the blade teeth as well as cutting line deflection (Giraud et al., 1991), (Ark et al., 1998), (Toksvig-Larsen et al., 1992), (Krause et al., 1982). In these types of the tissue cutting many fragments occur acting as foreign particles to which the organism reacts by aseptic inflammation in the point of the presence of chips through which the healing period is extended and consequently costs and post-operative care length 
Hloch, S.; Foldyna, J.; Monka, P.; Kozak, D. \& Magurova, D.: Advances in (Un)Co...

increase. Any of the used mechanical methods are characterized by the same attribute represented by attendance of a surgeon, i.e. a man, by which accuracy level significantly decreases and causes negative actions of force upon the bone tissue.

Notwithstanding heavy effort made by scientists and despite the increased requirements the current applicable techniques of osteotomy in orthopaedic surgery have changed minimally in the course of the last decades. One of the options of making surgical operations more effective is to use techniques working on the principle of photon erosion, water erosion, and ultrasound. An excimer laser was considered to be a suitable instrument to, for instance, remove the bone cement without the bone damaging (Zimmer et al., 1992). With regard to its low ablation rate clinical utilization in overall hip joint revision proved impossible as per.

Ritter and Campbell (Ritter \& Campbell, 1989) pointed out the fact that conditions of the femoral channel were crucial for successful revision alloplasty. It means that the bone cement must be completely eliminated with minimal damaging of the cortical or cancellous bone. Several methods have been described yet the best solution still remains unknown.

\begin{tabular}{|c|c|c|c|c|c|c|}
\hline & Osc. saw & Drilling & Chisel & Ultras-ound & Laser & Water Jet \\
\hline Selectivity & No & No & No & No & No & Yes \\
\hline Heat effect & Yes & Yes & No & Yes & Yes & No \\
\hline $\begin{array}{c}\text { Mechanical } \\
\text { effects }\end{array}$ & Yes & Yes & Yes & Yes & Yes & No \\
\hline $\begin{array}{c}\text { Pollution of } \\
\text { the } \\
\text { operating } \\
\text { field }\end{array}$ & Yes & Yes & Yes & Yes & Yes & No \\
\hline $\begin{array}{c}\text { Damage to } \\
\text { surrounding } \\
\text { tissue }\end{array}$ & Yes & Yes & Yes & Yes & Yes & N/A \\
\hline Fragments & Yes & Yes & Yes & No & No & No \\
\hline Easy handle & Yes & Yes & Yes & No & No & N/A \\
\hline Robotic use & No & Yes & No & Yes & Yes & Yes \\
\hline Cut gap & wide & wide & wide & wide & narrow & narrow \\
\hline
\end{tabular}

Tab. 2. Comparison of cutting techniques

Zimmer (Zimmer et al., 1992) mentioned that with the only excimer laser approved for medical use in Germany the ablation rate could not be sufficiently accelerated for all the bone cement in a hip revision operation to be removed in 
adequate time. Due to high photon energy excimer lasers induce radiation which may be used for electronic control of a laser ray through spectral difference between the bone and bone cement. Lasers used in the bone cutting up to now are still on the experimental level Lustman et al., 1991), (Nelson et al., 1988), (Biyikli \& Modest, 1987), (Siebert, 1993), (Jahn et al., 1992), (Wallace et al., 2004), (Armengol et al., 1999), (Yoshikazu, 2011), (Papadaki et al., 2007). As to geometry lasers are capable of an accurate cutting, yet reaching just shallow depths. Many scientists study the technique, for instance, Papadaki et al (Papadaki et al., 2007). An essential principle of interaction between a laser and biomaterial makes the technique unsuitable. Osteotomy requires the deep cutting possible to be carried out only by high-powered $\mathrm{CO}_{2}$ lasers (Biyikli \& Modest, 1987) causing instant unacceptable thermal damage of the tissue on the cutting surface (Giraud et al., 1991).

Use of ultrasound (Steiger et al., 1996), (Caillouette et al., 1991), (Klapper et al., 1992) devices is not common in surgical practice and still those are in the experimental development stage. The specialized ultrasound devices possess a distinctive function which excludes them out of the standard utilization in consequence of temperature increase unless a coolant is used. In spite of maximal effort the upgrades proposed by Volkov and Weis (Giraud et al., 1991) are not trouble free. The reason lies both in the amount of work within the restricted surgical field and thermal tissue damage.

Water jet is capable to cut any material in several directions without thermal and mechanical deformation of the cutting material (Hreha et al., 2010), (Kovacevic, 1991), (Sharma et al., 2011). The cutting principle rests in forcing the abrasive water jet or pure water jet to the point of the cutting at high speed. The permeate being the kinetic energy carrier of the abrasive washes the removal products off the point of the cutting and provides its cooling. As table 3 shows a high potential stems in the technology of the abrasive water jet cutting. The first medical applications of the technology were published in the 80s when the water jet was used to cut the soft tissues. In a large extent the water jet (WJ) is applied in all types of industry. In medicine practice the water is possible to be utilized, for instance, in cutting the organs; wound cleaning; liposuction; necrotic epidermis removal; extraction of metastasis and glioma; cutting the tissues, bones, tooth substance. Options of use of the water jet application and its advantages are described in (Hreha et al., 2010), (Kovacevic, 1991), (Honl et al., 2000), (Kuhlmann et al., 2005), (Richter et al., 2009), (Penchev et al., 1999), (Dunnen et al., 2013).

Nowadays the studies researching the use of the water jet even in orthopaedics, for instance, in implantations and reimplantations of total replacement of the hip and knee joints are available (Honl et al., 2000), (Honl et al., 2001), (Kuhlmann et al., 2005), (Honl et al., 2003). The objective is to draw attention to the fact that the AWJ may in the future replace so far exerted technological procedures to cut down on financial demands related to the surgical performance as well as to reduce the period of hospitalization and early return of a patient into the active life. 
Hloch, S.; Foldyna, J.; Monka, P.; Kozak, D. \& Magurova, D.: Advances in (Un)Co...

\begin{tabular}{|c|c|c|c|}
\hline Field & Using & Advantages & Ref. \\
\hline $\begin{array}{l}\text { Orthopaedi } \\
\text { cs }\end{array}$ & $\begin{array}{l}\text { Cutting the cemented } \\
\text { and uncemented } \\
\text { endoprostheses, bone } \\
\text { cement and bones }\end{array}$ & $\begin{array}{l}\text { does not reach critical } \\
\text { temperature in cutting }\end{array}$ & $\begin{array}{l}\text { (Honl et al., 2000) } \\
\text { (Honl et al., 2001) } \\
\text { (Kuhlmann et al., } \\
\text { 2005) } \\
\text { (Honl et al., 2003) } \\
\text { (Honl et al., 2003) } \\
\text { (Dunnen et al., 2013) }\end{array}$ \\
\hline Dentistry & $\begin{array}{l}\text { Tooth substance } \\
\text { cutting and abrading }\end{array}$ & $\begin{array}{l}\text { Decreases risk of tooth } \\
\text { chipping, decreases necessity } \\
\text { of anaesthetics }\end{array}$ & (Berry et al., 2011) \\
\hline Surgery & $\begin{array}{l}\text { Resection of soft } \\
\text { tissues: liver, gall } \\
\text { bladder, brain, } \\
\text { kidneys, prostate } \\
\text { gland, wound } \\
\text { cleaning }\end{array}$ & $\begin{array}{l}\text { blood vessels and nerve tissues } \\
\text { remain intact at defined } \\
\text { pressure, minimized bleeding, } \\
\text { accurate and intact cutting } \\
\text { edges, absence of necrotic } \\
\text { edge, shortening of ischaemia } \\
\text { period }\end{array}$ & $\begin{array}{c}\text { (Richter et al., 2009) } \\
\text { (Penchev et al., 1999) } \\
\text { (Hata et al., 1994) } \\
\text { (Cuschieri, 1994) } \\
\text { (Ogan \& Cadeddu, } \\
\text { 2002) } \\
\text { (Persson et al., 1989) } \\
\text { (Une et al., 1989) } \\
\text { (Birth et al., 2004) } \\
\text { (Smith, 1993) } \\
\text { (Papachristou, 1982) } \\
\text { (Baer et al., 1993) } \\
\text { (Andratschke et al., } \\
\text { 2011) } \\
\text { (Tschan et al., 2010) } \\
\text { (Tschan et al., 2009) } \\
\text { (Oertel et al., 2004) } \\
\text { (Oertel et al., 2003) }\end{array}$ \\
\hline $\begin{array}{l}\text { Plastic } \\
\text { surgery }\end{array}$ & $\begin{array}{l}\text { Dermal graft } \\
\text { cleaning, tattoo } \\
\text { removal, liposuction }\end{array}$ & $\begin{array}{l}\text { Separation of the tissue layers, } \\
\text { higher accuracy of results } \\
\text { exclusive of swellings and } \\
\text { contour changes }\end{array}$ & $\begin{array}{c}\text { (Berry et al., 2011) } \\
\text { (Man \& Mezer, 2007) } \\
\text { (Stutz \& Krahl, 2009) } \\
\text { (Araco et al., 2007) }\end{array}$ \\
\hline $\begin{array}{l}\text { Dermatolog } \\
\text { y, } \\
\text { hydrosurger } \\
\text { y }\end{array}$ & $\begin{array}{l}\text { Necrotic epidermis } \\
\text { removal }\end{array}$ & $\begin{array}{l}\text { possibility of direct } \\
\text { medicament dosing into the } \\
\text { water jet, elimination of burns, } \\
\text { treatment of bedsore }\end{array}$ & $\begin{array}{l}\text { (Gurunluoglu, 2007) } \\
\text { (Granick et al., 2006) } \\
\text { (Klein et al., 2005) }\end{array}$ \\
\hline
\end{tabular}

Tab. 3. Using Water Jet in medical fields

\section{Related Problems}

Latest knowledge of fundamental research (Johansson et al.1, 1981), (Canestri, 1992), (Sugita et al., 2005) and up-to-date technology have established conditions (Mitsuishi et al., 2003), (Taylor \& Stoianovici, 2003) and high potentials in the area of conventional orthopaedic surgical operations as for instance corrections of uneven length and deformations of limbs, osteosynthesis, but particularly in possibilities of replacements of worn-out degenerative joints either on the developing, inflammatory, 
traumatogenic, metabolic grounds or in the postoperative states (Biyikli \& Modest, 1987). Replacement of worn-out joints (alloplasty) offers new treatment possibilities. Number of patients suffering from degenerative joint diseases (osteoarthritis) has been continually increasing and due to seriousness, therapeutic complications and frequent patient/client individualization the disease represents significant medical, economic and social issue (Kl'oc, 2009). Progress being achieved in orthopaedics, specifically in the sphere of reconstructive surgery, allows partial even full return of a $\mathrm{p} / \mathrm{c}$ to normal life. Damaged joint replacement by the total endoprosthesis represents the most remarkable advance in the history of bone surgery (Hreha et al., 2010). For the patient the successful replacement of destroyed joint means improvement of mobility, pain relief and returning back to accomplish every day activities.

Many patients at working age come back to work after successful surgery of the hip joint (total endoprosthesis implantation). Implantation achievement of the total hip joint replacement and long-term longevity of endoprosthesis depend on a lot of factors involving correct indication, patient preparation, properly performed surgical operation, surgeon's skills, technical device, operating theatre conditions and postoperative care in which rehabilitation plays an important role. Number of the hip joint total endoprostheses in the world and Slovak Republic increases yearly (fig. 1, fig. 2) (Nečas et al., 1993). The presented development chart of number of alloplastic surgical operations of the hip and knee joints in the territory of the Slovak Republic draws on two sources: until 2003 it was statistics of the chief expert in orthopaedics of Ministry of Health of the Slovak Republic and since 2003 it has been the Slovak Arthroplasty Register (SAR) (Nečas et al., 1993). Gradually, application of the uncemented total hip joint replacements increases (Jackson et al., 2005) (Fig. 1).

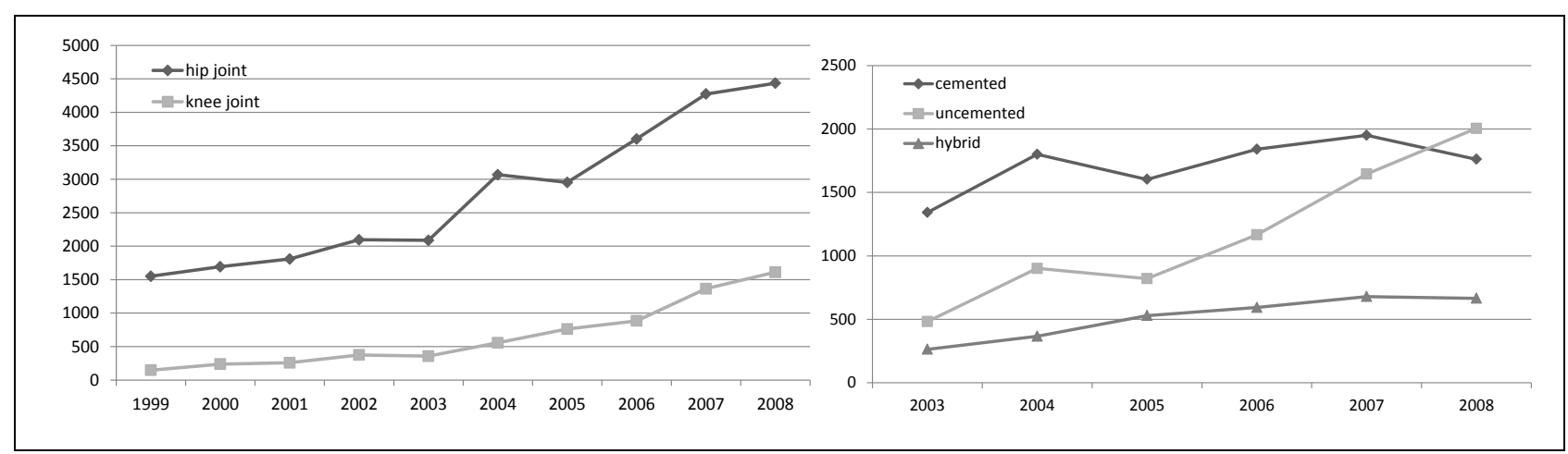

Fig. 1. Development of endoprosthetics (primarily), development of methods of the hip joint fixation (Nečas et al., 1993)

\section{Analysis of Surgical Procedure}

Technical innovations in the sphere of total replacement development include multifactor impact on diverse joint aspects (Kl'oc, 2009), (Hloch et al., 2013), (Kwon et al., 2002). New contemporary techniques of osteotomy procedures allow precise cut final grinding and thus optimal prosthesis placing in the bearing axis. The result of this highly exact procedure is more precise endoprosthesis fitting, fixation 
improvement and longevity (Jackson et al., 2005). Prior to each surgery related to the total endoprosthesis of the hip joint a preoperative planning is to be carried out allowing determining size of the endoprosthesis components, their position following the anchoring in order to retain the centre of rotation of the total replacement (Fig. 2).

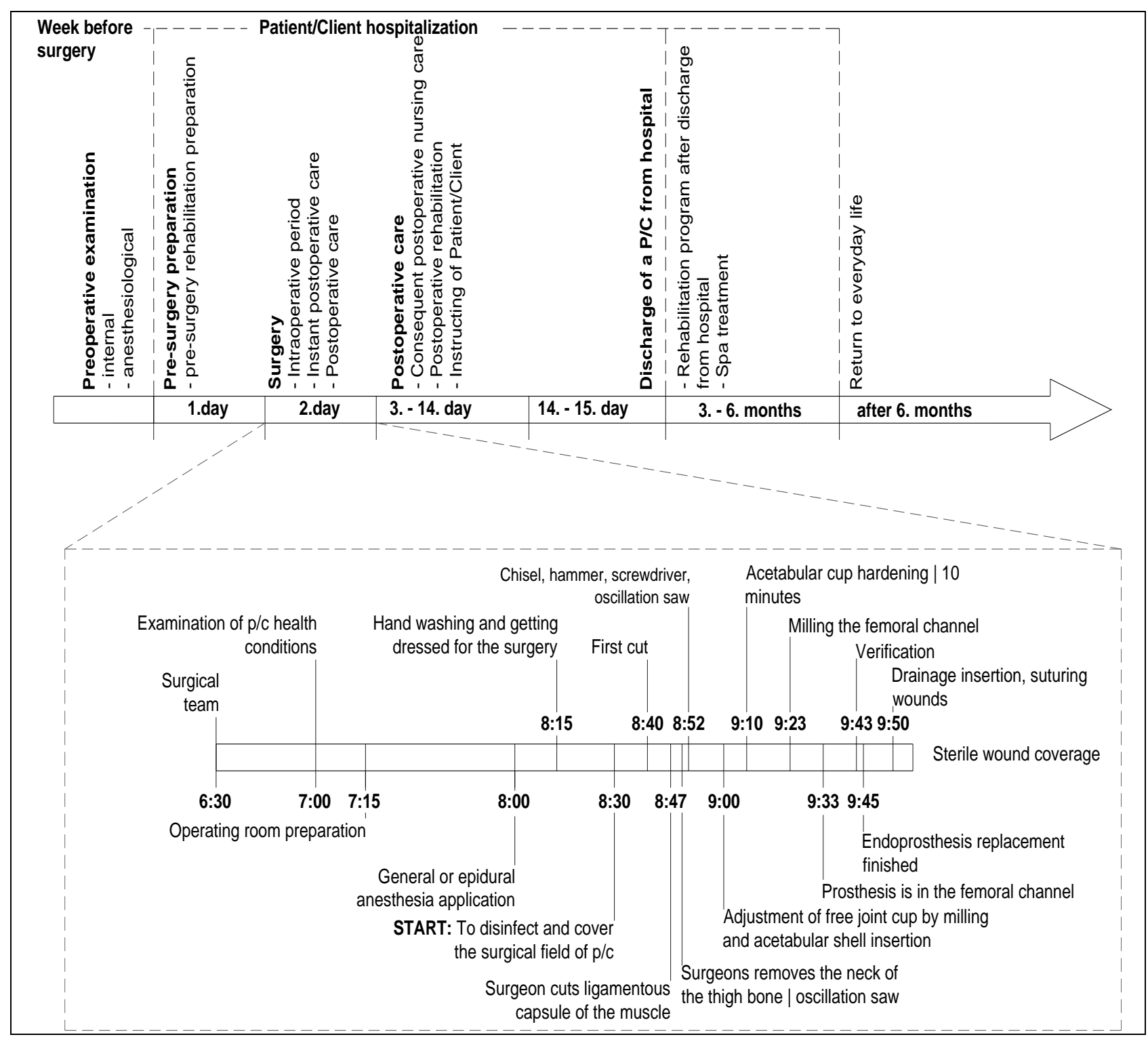

Fig. 2. Dynamic procedural analysis of hip joint replacement in the process of client vs. hospital care - (preoperative examination + diagnostics) - operative treatment postoperative care - client monitoring (source: authors archive)

The preoperative planning requires X-ray of the pelvis in the AP projection and the images of both hip joints in the axial projection. The planning of the size and position of the components is carried out using the templates. The surgery is possible to be performed using different operative approaches, according to the surgery type, and surgeon's usages. As per operative approach the operative technique and surgery procedure are different. In standard anterolateral approach following the preparation of the soft structure the hip joint is being opened up. Foremost the head with the neck is resected and then the joint cup of the acetabulum is proceeded to in order to be machined. The acetabulum is being machined by use of special milling cutters in 
accordance with the cup being implanted. Into the prepared socket of the acetabulum either the cemented cup is anchored using bone cement or the uncemented cup in case of which the polyethylene, metal or ceramic articulation liner is inserted into the anchoring part. Consequently, the femoral channel is prepared in case of which under the osteotomy line the metaphyseal area is being extended by means of fenestrated chisel. The chisel orientation has to retain the planned anteversion of the femmoral component. Using special milling cutters the marrow cavity is then milled with the milling cutters' size increasing in stages. Thereafter the cavity is prepared by rasps according to the implanted endoprosthesis type. A plastic head is inserted onto the last rasp size, displacement is performed, endoprosthesis stability is tested and the length of the limb is checked. In cemented endoprosthesis the cap made of polyethylene or spongious bone is inserted into the cavity below the tip of the femoral component and so is the drainage which drains haematoma out of distal pole of the marrow cavity allowing thus bone cement to be pressed into the marrow cavity. The centralizer of an adequate size is inserted into the opening of lower part of the stem. Following the drainage removal the stem is inserted into the femoral channel filled with bone cement in desired anteversion. When cement has grown mature the testing head, later changed into the definite one, is reinserted. Should the cementless stem be used it is placed into the prepared socket to provide fixed anchoring (Kl'oc, 2009).

\section{Pro-futuro Approach to Problems Being Solved}

Effective surgical process depends on technology. Due to many benefits of water jet it is possible to use kinetic energy of waterjet for destruction of bone cement - interface between femoral stem and trabecular bone in case of reimplantation of femoral stems (Fig. 5). There is an advantage of using water jets coming from the fact that the jet is able to remove selectively the material with lower modulus of elasticity (titanium endoprosthesis exhibits modulus of elasticity $E \mathrm{Ti}=200 \mathrm{GPa}$, bone cement (PMMA) $E \mathrm{bc}=4,5 \div 4,8 \mathrm{GPa}$ (Fig. 3), and trabecular bone tissue Ebone = 14,8 GPa (Rho et al., 1993)). Considering low values of mechanical characteristics of bone cement the water jet flow shall cold-create a crack between a trabecular part of bone structure and the stem of the femoral component without mechanical damage or deformation to surrounding tissue during process of releasing of the stem of the component. This hypothesis was partially experimentally verified in following study (Hloch et al., 2013). Results from performed experiments show that the pulsating water jet is a suitable technology for bone cement removal due to the lowest pressures necessary for disintegration of bone cement. Further research will be aimed at the evaluation of disintegration of different kinds of bone cements commercially used in orthopedic practice. 
Hloch, S.; Foldyna, J.; Monka, P.; Kozak, D. \& Magurova, D.: Advances in (Un)Co...

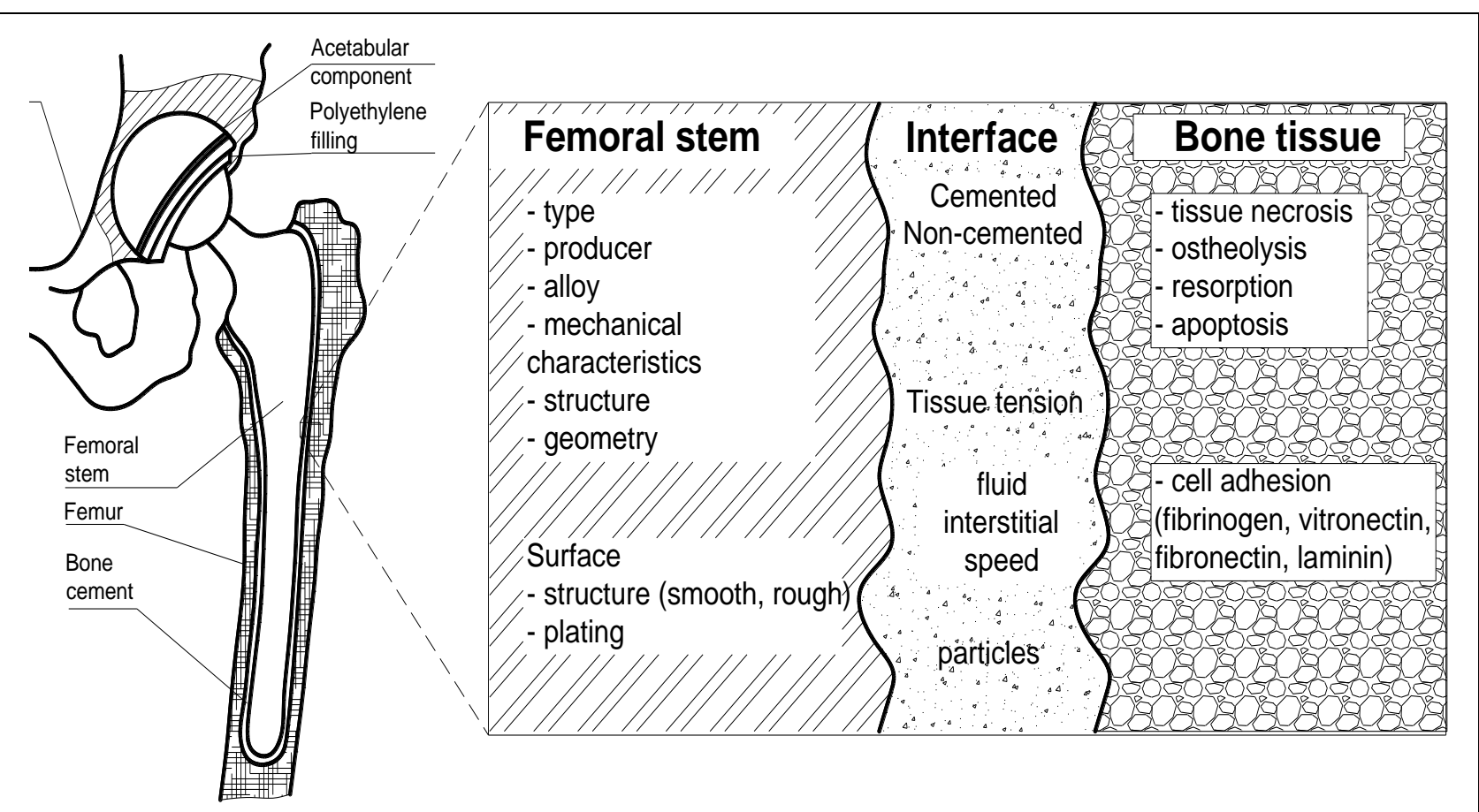

Fig. 3. Interface model of implant and bone tissue where, $E_{i}=200 \mathrm{GPa}, E_{c e m}=5 \mathrm{GPa}$, $E_{\text {Bone }}=14,8 \mathrm{GPa}$

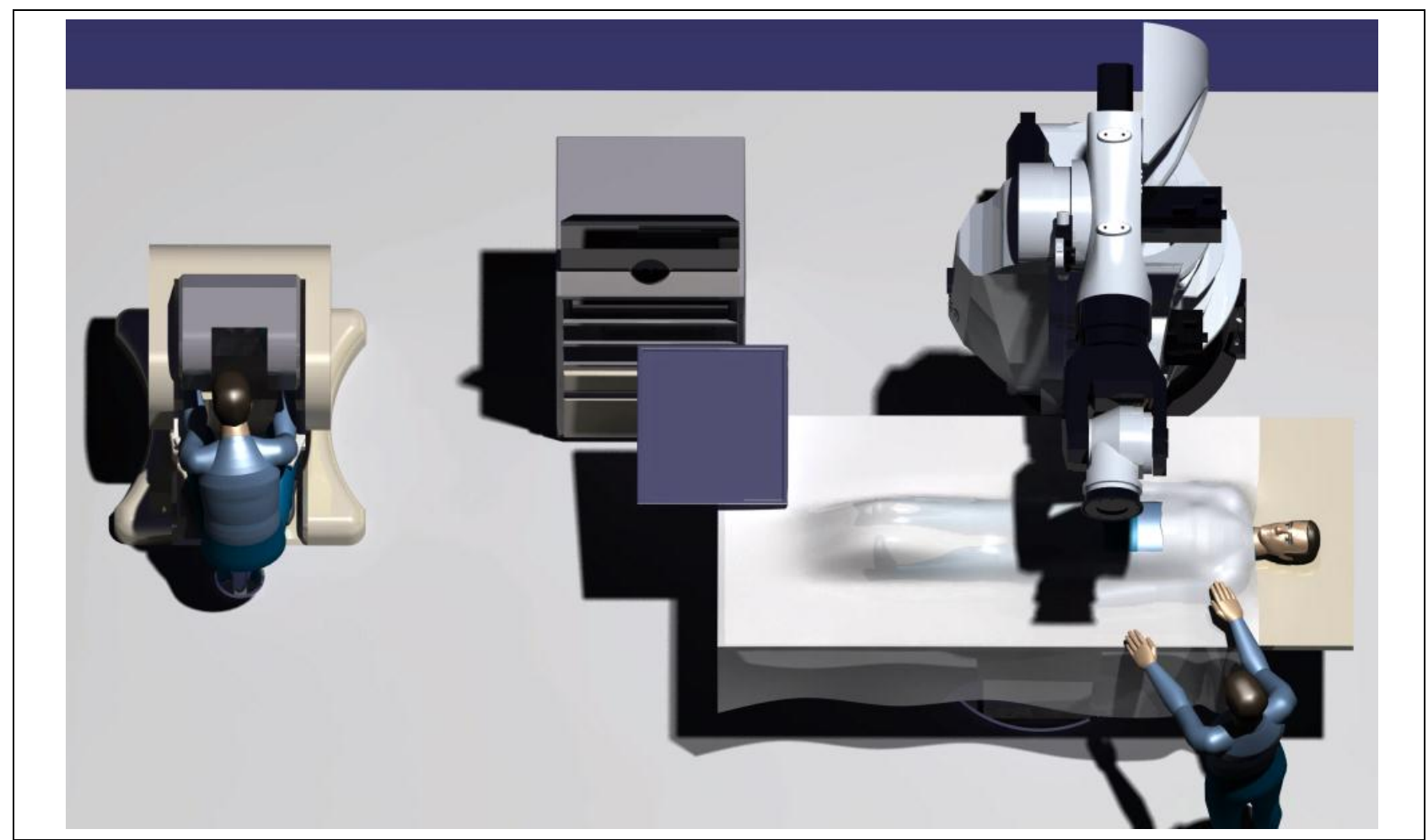

Fig. 4. An example of pro-futuro workplace with the on-line control of surgical resection of the hip joint or reimplantation of total replacements of hip and knee joints by the abrasive water jet technology (source: Martina Blichova)

Other advantages represent small losses, quick and considerate technological process of cutting of even heavy porous bones. Considering its broad utilization the technology appears to be used especially in case of reimplantations. Diameter of the water jet up to $0.5 \mathrm{~mm}$ means remarkable advantage while working in very small 
areas at interface of the prosthesis and bone tissue. The cutting process is basically cold, thus thermal effect is avoided, and forces and reactions are relatively low. Accurate manipulation with an applicator is possible both in manual or robotic way. Given facts show possibility to remove prosthesis by the technique of cutting in quicker and more considerate manner. The following figures 4,5 shows the part of proposed workplace with application of automated on-line control of surgical resection of the hip joint using technology of abrasive water jet being solved within the thesis by Blichová.

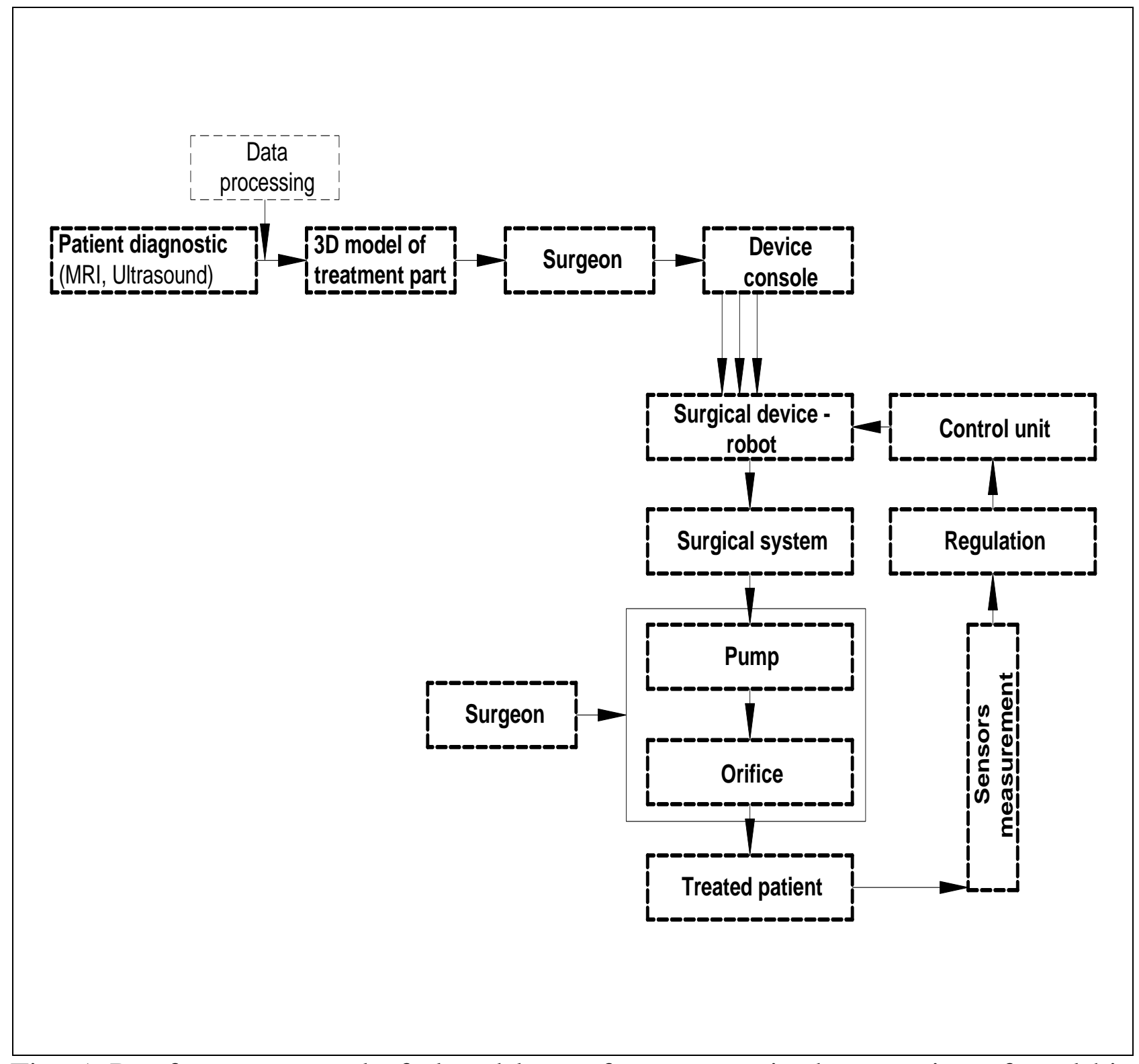

Fig. 5. Pro-futuro proposal of closed loop of an automatised processing of total hip replacement and endoprothesis reimplantation

\section{Conclusion, Remarks and Future direction of Research}

New technologies are still introduced even in orthopaedic practice with a promise of better care of patients, though often with limited pieces of information. 
Hloch, S.; Foldyna, J.; Monka, P.; Kozak, D. \& Magurova, D.: Advances in (Un)Co...

Therefore hospitals, medical establishments, and surgeons face a need to evaluate relative advantages of new technologies to be able to consider possible benefits for patients. The aim is to decrease costs and potential undesirable clinical impacts connected with their use. This scientific research work is based upon possibility to apply the abrasive water jet cutting technology. It comprises outcomes of exploration and possibilities of utilization of the abrasive water jet cutting technology for purpose of responsible and profitable introduction of the technology in orthopaedic practice. Innovation of the exerted surgical procedures with utilization of the water jet in medicine is a vision to the near future with solid foundation in fierce competitive market environment. A joint effort in the future shall be aimed at:

- carrying out quite a number of experiments and research studies in the field of basic research with consequent implementation of the applied research in the field of medicine and nursing practice,

- realizing and monitoring the results of the applied research in the field of impact of surgical orthopaedic performances related to total endoprosthesis and reimplantation with utilization of the water jet.

Partial objectives specified within the field of technical disciplines, medicine, and nursing:

- in the field of technical disciplines the objectives shall be aimed at:

- prediction of the quality of the surfaces generated by the water jet cutting,

- examination of the alternative biocompatible material and its influence upon the quality and efficiency of the process to arrange strict aseptic environment in terms of surgical operation,

- study of relation between the surface quality and change of technological conditions of assessment of eligibility of the bone tissue cutting process,

- development of sterile pumps and the cutting depth check,

- optimizing regime factors of the water jet for the future robotic utilization,

- elaborating a proposal of the on-line control of a surgical process,

- controlling the penetration process of the water jet,

- integration of general theoretical prognosis of the reached limit depths,

- unification of interpretations and results to achieve a high level of generalization for other workplaces.

In the field of surgical medicine to:

- point out the possibilities of quality enhancement of the surgical operation using the water jet related to technological procedure of the hip join replacement,

- monitor the cutting quality,

- monitor comfort of the surgical field, length of a surgical operation, $\mathrm{p} / \mathrm{c}$ 's remaining under anaesthesia, etc. 
At the field of nursing:

- to describe contribution for the nursing practice,

- to monitor impact of a new surgical technology upon a patient/client $(\mathrm{p} / \mathrm{c})$,

- to point out particularities of nursing care,

- to compare a current rehabilitation program with a program using the technology in question,

- to monitor $\mathrm{p} / \mathrm{c}$ 's hospitalization length,

- impact upon management of the rendered nursing care and $\mathrm{p} / \mathrm{c}$ 's life quality after the total hip joint replacement,

- to elaborate standards and audit for a complex nursing care of a $\mathrm{p} / \mathrm{c}$ after the total endoprosthesis surgical operation using the latest surgical technology,

- to monitor quality of postoperative process as well as of elimination of postoperative complications in consequence of early mobilization,

- to monitor a p/c's life quality and related overall social and economical impact.

Surgical operations using the water jet represent a potential instrument to enhance both surgical operations in favour of patient's life quality improvement and eventually general social and economical impact. Innovation of the exerted surgical procedures with utilization of the water jet in medicine is a vision to the near future with good foundation in a fierce competitive environment. In spite of considerable advance in the application of the water jet technology we are aware of the problems related to its application in clinical practice and thus we do believe that by the contribution a possible discussion focused on the field in question shall be initiated.

The purpose was not to draw attention to a detailed description of a $\mathrm{p} / \mathrm{c}$ nursing care management after TEP yet to centre on feasible innovative therapeutic techniques using the water jet in orthopaedics and orthopaedic nursing. At the same time the desire was aimed at outlining the option of multidisciplinary connection in the field of medicine, nursing, and technical disciplines. The fundamental idea was requirement to provide a $\mathrm{p} / \mathrm{c}$ with nursing care based on knowledge of latest outcomes of a scientific research. A surgery related to TEP, utilizing water jet, represents a viable instrument for surgery enhancement. In perspective, it would be suitable, for instance, to work out standards and audit for complex nursing care of a $\mathrm{p} / \mathrm{c}$ after TEP surgery with application of a new surgical technology, monitoring of comfort of a surgical field, length of the surgery, keeping a p/c under anaesthesia, quality of after-surgical development with a p/c as well as elimination of surgical complications due to earlier mobilisation. Last but not least the focus was directed towards benefits in the sense of increasing quality of life of a $\mathrm{p} / \mathrm{c}$ and thus related overall social and economic impact. However, quite a number of studies as well as activities should be performed aimed at support and development of theoretical basis of medical and nursing research with further implementation in clinical practice. To 
Hloch, S.; Foldyna, J.; Monka, P.; Kozak, D. \& Magurova, D.: Advances in (Un)Co...

acquire knowledge for more detailed description of the process it is inevitable to define indications and eventual contraindications in application of the water jet in medicine.

\section{Acknowledgments}

Experiments were carried out under the support of projects science and research VEGA 1/0972/11, VEGA 2/0075/13, Institute of clean technologies for mining and utilization of raw materials for energy use, reg. no. CZ.1.05/2.1.00/03.0082 supported by the Research and Development for Innovations Operational Programme financed by the Structural Funds of the European Union and the state budget of the Czech Republic, and with support for the long term conceptual development of the research institution RVO:68145535.

\section{References}

Andratschke M.; Loerken J.; Eggers R.; et al. (2011) Histomorphologic findings in the facial nerve after waterjet dissection of the parotid gland. Animal studies in dogs HNO 59: 1055-1061

Ark TW, Neal JG, Thacker JG, Edlich RF (1998) Influence of irrigation solutions on oscillating bone saw blade performance. J Biomed Mater Res 1998; 43: 108-112.

Armengol V.et al (1999) Scanning electron microscopic analysis of diseased and healthy dental hard tissues after ErYAG laser irradiation: in vitro study, J. Endodont. 25 (8) (1999) 543-546

Baer HU, Stain SC, Guastella T, Maddern GJ, Blumgart LH. (1993) Hepatic resection using a water jet dissector. HPB Surg 1993;6(3):189-96

Berry MG, Davies D. (2011) Liposuction: A review of principles and techniques. Journal of Plastic, Reconstructive \& Aesthetic Surgery, 2011, 64 (8), p.985-992 Vol. 57, 1(2012), p. 30-35

Berry MG, Davies D. (2011) Liposuction: A review of principles and techniques. Journal of Plastic, Reconstructive \& Aesthetic Surgery, 2011, 64 (8), p.985-992

Birth M; Kleemann M; Hildebrand P; et al. (2004) Intraoperative online navigation of dissection of the hepatical tissue - a new dimension in liver surgery? DOI: 10.1016/j.ics.2004.03.335

Biyikli S, Modest MF. (1987) Energy requirements for osteotomy of femora and tibiae with a moving CW CO2 laser. Lasers Surg Med 1987; 7: 512-519.

Caillouette JT, Gorab RS, Klapper RC, Anzel SH. (1991) Revision arthroplasty facilitated by ultrasonic tool cement removal. Part I: In vitro evaluation. Orthop Rev 1991;20: 353-357

Canestri F. (1992) Proposal of a computerized algorithm for continuous wave CO2 laser on-line control during orthopaedic surgery. Phase I: theoretical introduction and first in vitro trials. Int J Clin Monit Comput 1992;9: 31-44 
Cuschieri A. (1994) Experimental evaluation of water-jet dissection in endoscopic surgery. Endosc Surg Allied Technol 1994;2(3-4):202-4

Dunnen, D. et al. (2013) Pure water jet drilling of articular bone: An in vitro feasibility study. Strojniski Vestnik/Journal of Mechanical Engineering 59 (7-8), pp. 425-432

Eriksson, R. A.; Albrektsson, T. (1984) The effect of heat on bone regeneration: an experimental study in the rabbit using the bone growth chamber. J. Oral Maxillofac. Surg. 42: 705-711; 1984

Foldyna J. et al. (2004) Utilization of ultrasound to enhance high-speed water jet effects // Ultrasonic sonochemistry. vol.11, 3-4(2004), p. 131-137

Giraud JY, et al. (1991) Bone cutting. Clin.Physics and Physiological Measurement.doi:10.1088/0143-0815/12/1/001

Goran A, et al (2012) Cortical bone drilling and thermal osteonecrosis. Clinical Biomechanics, vol. 27, 4, pp. 313-325

Granick MS, et al. (2006) Clinical and economic impact of hydrosurgical debridement on chronic wounds. Wounds 2006, 18:35-39

Gurunluoglu, R. (2007) Experiences with waterjet hydrosurgery system in wound debridement. World Journal of Emergency Surgery. 2007, doi:10.1186/1749-7922-210

Haider, H. et al. (2007) Minimally Invasive Total Knee Arthroplasty Surgery Through Navigated Freehand Bone Cutting. The Journal of Arthroplasty Vol. 22, 4(2007), p. 535-542

Hata Y, et al. (1994) Liver resection in children, using a water-jet. J Pediatr Surg 1994; 29: 648-650

Hloch S et al. (2013) Dissintegration of bone cement by continual and pulsating water jet. Vol.20 No.4, pp. 593-598

Honl M, et al. (2001) Water jet discotomy with microinvasive approach-in vitro testing and initial clinical aspects of a new procedure. Z Orthop Ihre Grenzgeb 2001; 139: 45-51

Honl M, et al. (2000) The use of water-jetting technology in prostheses revision surgery-first results of parameter studies on bone and bone cement. J Biomed Mater Res 2000; 53: 781-790

Honl M, et al. (2000) Water jet cutting for bones and bone cement—parameter study of possibilities and limits of a new method. Biomed Tech Berlin 2000; 45: 222-227

Honl M; Uebeyli H; Dierk O; et al. (2003) Use of a waterjet for synovectomy: In vitro study of feasibility. Zeitschrift fur Orthopadie und ihre Grenzgebiete 141:322327

Hreha, P., Hloch, S., Magurová, D., et al. (2010) Water jet technology used in medicine. // Tehnički vjesnik. vol. 17, no. 2 (2010), p. 237-240

Jackson MJ et al. (2005) Machining Cancellous Bone prior to prosthetic implantation. Journal of Materials Engineering and Performance International. (2005) 14:293-300 Jahn R, Dressel M, Neu W, Jungbluth KH. Ablation of hard biological tissue with the excimer laser. Unfallchir 1992; 18: 261-265 
Johansson JE, et al. (1981) Fracture of the ipsilateral femur in patients with total hip replacement. J Bone Joint Surg Am 1981;63: 1435-1442

Kato N, Koshino T, Saito T, Takeuchi R. (1998) Estimation of Young's modulus in swine cortical bone using quantitative computed tomography. Bull Hosp Jt Dis. 1998;57(4):183-6

Klapper RC, Caillouette JT, Callaghan JJ, Hozack WJ. (1992) Ultrasonic technology in revision joint arthroplasty. Clin Orthop 1992; 147-154

Klein MB, et al. (2005) The Versajet water dissector: a new tool for tangential excision. J Burn Care Rehabil 2005, 26:483-487

Kl'oc, J. (2009) Solutions disorders hip replacements, leading to reoperation. $\mathrm{PhD}$ Thesis, Technical University of Košice, 2009, p. 117

Kovacevic R. (1991) Surface texture in abrasive waterjet cutting. J Manufact Syst 1991; 10: 32-40.

Krause, W. R.; Bradbury, D. W.; Kelly, J. E.; Lunceford, E. M. (1982) Temperature elevations in orthopedic cutting operations. J. Biomech. 15: 267-275; 1982

Kuhlmann C; Pude F; Bishup C; et al. (2005) Evaluation of potential risks of abrasive water jet osteotomy in-vivo. Biomedizinische Technik 50:337-342

Kušnerová, M. et al. (2008) Derivation and measurement of the velocity parameters of hydrodynamics oscillating system. // Strojarstvo: Journal for theory and application in mechanical engineering. vol. 50, no. 6 (2008), p. 375-379

Kwon D.S., et al. (2002) The Mechanism and the Registration Method of a Surgical Robot for Hip Arthroplasty", IEEE International Conference of Robotics and Automation, pp. 1889-1894, 2002

Lee $\mathbf{J}$ et al. (2011) A new thermal model for bone drilling with applications to orthopaedic surgery. Medical Engineering \& Physics 33 (2011), p. 1234- 1244

Lustmann J, et al. $193 \mathrm{~nm}$ excimer laser ablation of bone. Lasers Surg Med 1991; 11: $51-57$

Man D, Meyer H. Water jet-assisted lipoplasty. Aesthetic Surg J 2007;27:342-6.

Mitsuishi M., et al., Development of a 9 Axes Machine Tool for Bone Cutting, Annals of the CIRP, 52/1 (2003) 323

Mitsuishi, M. et al. (2002) A Study of Bone Micro-Cutting Characteristics Using a Newly Developed Advanced Bone Cutting Machine Tool for Total Knee Arthroplasty. CIRP-Annals of Manufacturing Technology. Vol. 54, 1(2005), p. 41-46 Nečas, L et al. (1993) Slovak arthroplastic register - analysis. $2003 \div 2008$, 2009, pp. 325

Nelson CL, Weber MJ. (1981) Technique of windowing the femoral shaft for removal of bone cement. Clin Orthop 1981; 336-337

Nelson JS, et al. (1988) Ablation of bone and methacrylate by a prototype midinfrared erbium:YAG laser. Lasers Surg Med 1988; 8: 494-500

O'Daly, B. et al. (2008) High-power low-frequency ultrasound: A review of tissue dissection and ablation in medicine and surgery. Journal of Materials Processing Technology. Volume 200, Issues 1-3, Pages 38-58. 8 May 2008. (O'Daly et al., 2008) 
Oertel J, Gaab MR, Piek J. (2003) Waterjet resection of brain metastases - first clinical results with 10 patients. Eur J Surg Oncol 2003;29(4):407-14

Oertel J; Gaab MR; Schiller T; et al. (2004) Towards waterjet dissection in neurosurgery: experimental in-vivo results with two different nozzle types. Acta Neurochirurgica. 146:713-720

Oertel J; Gaab MR; Warzok R; et al. (2003) Waterjet dissection in the brain: review of the experimental and clinical data with special reference to meningioma surgery. Neurosurgical Review 26:168-174

Ogan K, Cadeddu JA. (2002) Minimally invasive management of the small renal tumor: review of laparoscopic partial nephrectomy and ablative techniques. J Endourol 2002;16(9):635-43

Papachristou DN, Barters R. (1982) Resection of the liver with a water jet. Br J Surg 1982;69(2):93-4

Papadaki, M. et al. (2007) Vertical ramus osteotomy with Er:YAG laser: a feasibility study. Int. J. Oral Maxillofac. Surg. 36(2007), p. 1193-1197

Penchev RD; Losanoff JE; Kjossev KT (1999) Reconstructive renal surgery using a water jet. Journal of Urology. 162:772-774

Persson BG, Jeppsson B, Tranberg KG, Roslund K, Bengmark S. (1989) Transection of the liver with a water jet. Surg Gynecol Obstet 1989;168(3):267-8

Rho, J. Y.; Ashman, R. B.; Turner, C. H. (1993) Young's modulus of trabecular and cortical bone material: ultrasonic and microtensile measurements. // J Biomech. 26, 2(1993), pp. 111-119

Richter S. Kollmar O. Schuld J. et al. (2009) Randomized clinical trial of efficacy and costs of three dissection devices in liver resection. British Journal Of Surgery 96: 593-601

Ritter MA, Campbell ED (1989) The survival of the cemented femoral component of a total hip replacement. Clin Orthop $243: 143-147$

S.Biyikli, M.F.Modest and R.Tarr (1986) Measurements of thermal properties for human femora, J.Biomedical Materials Res., 20/9 (1986) 1335

Salgado AJ, Coutinho OP, Reis LR. (2004) Bone tissue Engineering: State of teh Art and Future Trends. Macromol. Biosci. 2004, 4, 743-765

Sharma V., Chattopadhyaya S., Hloch S. (2011) Multi response optimization of process parameters based on Taguchi-Fuzzy model for coal cutting by water jet technology // International Journal of Advanced Manufacturing Technology. Vol. 56, 9-12(2011), p. 1019-1025

Siebert W. (1993) Osteotomy with the experimental laser system. Fortschr Kiefer Gesichtschir 1993; 38: 149-151

Smith JA. (1993) Possible venous air embolism with a new water jet dissector. Br J Anaesth 1993;70(4):466-7

Steiger RN, Pandey R, McLardy-Smith P. (1996) Ultrasonically driven tools. J Arthroplasty 1996;11: 120-121

Stutz JJ, Krahl D. (2009) Water jet-assisted liposuction for patients with lipoedema: histologic and immunohistologic analysis of the aspirates of 30 lipoedema patients. Aesthetic Plast Surg 2009;33:153-62. Araco A, Gravante G, Araco F, et al. (2007) 
Hloch, S.; Foldyna, J.; Monka, P.; Kozak, D. \& Magurova, D.: Advances in (Un)Co...

Comparison of power water-assisted and traditional liposuction: a prospective randomized trial of postoperative pain. Aesthetic Plast Surg 2007;31:259-65

Sugita $\mathrm{N}$ et al. (2009) Cutting tool protects for soft tissues in bone milling machining. Int. J. of Automation Technology Vol.3No.2, 2009, pp. 185-186

Sugita N et al. (2009) Dynamic controlled milling process for bone machining Journal of Materials Processing Technology 209(2009), p. 5777-5784

Sugita N, Mitsuishi M (2009) Specifications for machining the bovine cortical bone in relation to its microstructure Journal of Biomechanics 42(2009), p. 2826-2829

Sugita, N. et al (2009) A new cutting method for bone based on its crack propagation characteristics. Cirp Annals - Manufacturing Technology 58(2009), p. 113-118

Sugita, N., Warisawa, S. and Mitsuishi, M., (2005) "A cutting temperature study of bone machining for orthopaedic robotic surgery". Proceedings of the 20th Annual Meeting of the ASPE, pp. pp. 142-145

Taylor RH., Stoianovici D (2003) "Medical Robotics in Computer-Integrated Surgery", IEEE Trans. On Robotics and Automation, Vol. 19, No. 5, pp. 765-781, 2003

Toksvig-Larsen, S et al. (1992) Temperature influence in different orthopaedic saw blades, The J. Arthroplasty 7 (1) (1992) 21-24

Toksvig-Larsen, S.; Ryd, L.; Lindstrand, A. (1991) On the problem of heat generation in bone cutting: studies on the effects of liquid cooling. J. Bone Joint Surg. 73B: 13-15; 1991

Tschan C. A.; Tschan K.; Krauss J. K.; et al. (2009) First experimental results with a new waterjet dissector: Erbejet 2 Acta Neurochirurgica 151:1473-1482

Tschan Christoph A.; et al. (2010) Waterjet Dissection of Peripheral Nerves: An Experimental Study of the Sciatic Nerve of Rats. 67: ons368

Tschan Christoph; Gaab Michael Robert; Krauss Joachim Kurt; et al. (2009) Waterjet dissection of the vestibulocochlear nerve: an experimental study Laboratory investigation. 110:656-661

Udiljak, T., Ciglar D., Skoric, S. (2007) Investigation into bone drilling and thermal bone necrosis. Advances in Production Engineering and Management, vol. 2, 3(2007), p. 103-112

Une Y, Uchino J, Horie T, Sato Y, Ogasawara K, Kakita A, et al. (1989) Liver resection using a water jet. Cancer Chemother Pharmacol 1989;23 Suppl:S74-77.

Wächter, R.; Stoll, P. (1991) Increase of temperature during osteotomy. J. Oral Maxillofac. Surg. 20: 245-249; 1991

Wallace RJ, et al. (2004) Experimental evaluation of laser cutting of bone. Journal of Materials Processing Technology 149 (2004) 557-560

Yoshikazu O. (2011) Pulsed laser-induced liquid jet for skull base tumor removal with vascular preservation through the transsphenoidal approach: a clinical investigation Acta Neurochirurgica 153: 823-830

Zimmer M. et al. (1992) Bone-cement removal with the excimer laser in revision arthroplasty. Arch Orthop Trauma Surg (1992) 112:15-17 